\title{
DEMAM REUMATIK AKUT
}

\author{
Julia Fitriany $^{1}$, Iis Annisa ${ }^{2}$ \\ ${ }^{1}$ SMF Ilmu Kesehatan Anak Fakultas Kedokteran, Universitas Malikussaleh, Aceh, Indonesia \\ ${ }^{2}$ Program Studi Profesi Dokter, Fakultas Kedokteran, Universitas Malikussaleh, Aceh, Indonesia
}

Corresponding author: iisanisa128@gmail.com

\begin{abstract}
Abstrak
Demam reumatik akut adalah konsekuensi autoimun dari infeksi streptokokus grup A. Demam reumatik akut menyebabkan respon inflamasi umum dan penyakit yang mengenai jantung, sendi, otak dan kulit secara selektif. Infeksi Streptococcus beta hemolyticus grup A pada tenggorok selalu mendahului terjadinya demam reumatik, baik pada serangan pertama maupun serangan ulangan. Manifestasi klinis demam reumatik dibagi menjadi manifestasi klinis mayor yaitu artritis, karditis, korea, eritema marginatum dan nodulus subkutan. Manifestasi klinis minor yaitu demam, artralgia, peningkatan LED dan C-reactive protein dan pemanjangan interval PR. Penatalaksanaan pada demam reumatik/penyakit jantung reumatik berupa eradikasi dari kuman Streptococcus beta hemolyticus grup A, obat-obat analgesik dan antiinflamasi, diet, istirahat dan mobilisasi serta pengobatan lain yang diberikan sesuai klinisnya seperti pengobatan korea.
\end{abstract}

Kata Kunci: Demam reumatik akut, Streptococcus beta hemolyticus grup A

\section{Acute Rheumatic Fever}

\begin{abstract}
Acute rheumatic fever is an autoimmune consequence of group A streptococcal infection. Acute rheumatic fever causes a general inflammatory response and diseases that affect the heart, joints, brain and skin selectively. Group A beta hemolyticus Streptococcus infection in the throat always precedes the occurrence of rheumatic fever, both in the first attack and repeated attacks. Clinical manifestations of rheumatic fever are divided into major clinical manifestations, namely arthritis, carditis, korea, erythema marginatum and subcutaneous nodules. Minor clinical manifestations include fever, arthralgia, increased LEDs and C-reactive protein and prolongation of the PR interval. Management of rheumatic fever / rheumatic heart disease in the form of eradication of the Streptococcus beta hemolyticus germ group A, analgesic and anti-inflammatory drugs, diet, rest and mobilization and other treatments given according to clinical such as Korean medicine.
\end{abstract}

Keywords: acute rheumatic fever, group A Streptococcus beta hemolyticus 


\section{PENDAHULUAN}

Demam reumatik akut adalah konsekuensi autoimun dari infeksi streptokokus grup A. Demam reumatik akut menyebabkan respon inflamasi umum dan penyakit yang mengenai jantung, sendi, otak dan kulit secara selektif. ${ }^{1}$ Penyakit ini cenderung berulang dan dipandang sebagai penyebab terpenting penyakit jantung didapat pada anak dan dewasa muda di seluruh dunia. ${ }^{2}$

Puncak insiden demam reumatik akut terdapat pada kelompok usia 5-15 tahun, penyakit ini jarang dijumpai pada anak dibawah usia 4 tahun dan penduduk di atas 50 tahun. ${ }^{3}$ Demam rematik dan penyakit jantung rematik menyebabkan meningkatnya ketidakhadiran di sekolah dan putus sekolah, dan kehilangan upah. Sekitar 30 juta orang saat ini diperkirakan terkena penyakit jantung rematik secara global, dan pada 2015 penyakit jantung rematik diperkirakan bertanggung jawab 305.000 kematian dan 11,5 juta tahun kehidupan yang disesuaikan dengan disabilitas hilang. Dari kematian ini $60 \%$ terjadi sebelum waktunya (yaitu, sebelum usia 70 tahun), meskipun angkaangka ini sangat tidak pasti karena data yang tidak lengkap di banyak negara. ${ }^{4}$

Prevalensi demam reumatik akut di Indonesia belum diketahui secara pasti, meskipun beberapa penelitian yang pernah dilakukan menunjukkan bahwa prevalensi penyakit jantung reumatik anak berkisar 0,3 sampai 0,8 per 1.000 anak sekolah. Dengan demikian, secara kasar dapat diperkirakan bahwa prevalensi demam reumatik akut di Indonesia pasti lebih tinggi dan angka tersebut, mengingat penyakit jantung reumatik anak merupakan akibat dari demam reumatik akut. ${ }^{5}$

\section{DEFINISI}

Demam rematik adalah penyakit inflamasi akibat reaktivitas-silang antibody seteah infeksi Streptococcus beta hemolyticus grup A . ${ }^{6}$

\section{ETIOLOGI}

Demam reumatik, seperti halnya dengan penyakit lain merupakan akibat interaksi individu, penyebab penyakit dan faktor lingkungan ${ }^{7}$. Infeksi Streptococcus beta hemolyticus grup A pada tenggorok selalu mendahului terjadinya demam reumatik, baik pada serangan pertama maupun serangan ulangan. Untuk menyebabkan serangan demam reumatik, Streptokokus grup A harus menyebabkan infeksi pada faring, bukan 
hanya kolonisasi superficial. Berbeda dengan glumeronefritis yang berhubungan dengan infeksi Streptococcus di kulit maupun di saluran napas, demam reumatik agaknya tidak berhubungan dengan infeksi Streptococcus di kulit.Hubungan etiologis antara kuman Streptococcus dengan demam reumatik diketahui dari data sebagai berikut: ${ }^{7}$

1. Pada sebagian besar kasus demam reumatik akut terdapat peninggian kadar antibodi terhadap Streptococcus atau dapat diisolasi kuman beta-Streptococcus hemolyticus grup A, atau keduanya.

2. Insidens demam reumatik yang tinggi biasanya bersamaan dengan insidens oleh beta-Streptococcus hemolyticus grup A yang tinggi pula. Diperkirakan hanya sekitar 3\% dari individu yang belum pernah menderita demam reumatik akan menderita komplikasi ini setelah menderita faringitis Streptococcus yang tidak diobati.

3. Serangan ulang demam reumatik akan sangat menurun bila penderita mendapat pencegahan yang teratur dengan antibiotika.

\section{PATOGENESIS}

Hubungan antara infeksi infeksi Streptokokus $\beta$ hemolitik grup A dengan terjadinya DR telah lama diketahui. Demam rematik merupakan respons auto immune terhadap infeksi Streptokokus $\beta$ hemolitik grup A pada tenggorokan. Respons manifestasi klinis dan derajat penyakit yang timbul ditentukan oleh kepekaaan genetic host, keganasan organisme dan lingkungan yang kondusif. Mekanisme patogenesis yang pasti sampai saat ini tidak diketahui, tetapi peran antigen histokompatibility mayor, antigen jaringan spesifik potensial dan antibody yang berkembang segera setelah infeksi streptokokkus telah diteliti sebagai faktor resiko yang potensial dalam patogenesis penyakit ini. ${ }^{8}$

Terbukti sel limfosit $\mathrm{T}$ memegang peranan dalam patogenesis penyakit ini dan ternyata tipe $\mathrm{M}$ dari Streptokkokus grup A mempunyai potensi rheumatogenik. Beberapa serotype biasanya mempunyai kapsul, berbentuk besar, koloni mukoid yang kaya dengan M-protein. M-protein adalah salah satu determinan virulensi bakteri, strukturnya homolog dengan myosin kardiak dan molecul alpha-helical coiled coil, seperti tropomyosin, keratin dan laminin. Laminin adalah matriks protein ekstraseluler yang disekresikan oleh sel endothelial katup jantung dan bagian integral dari struktur 
katup jantung. Lebih dari $130 \mathrm{M}$ protein sudah teridentifikasi dan tipe 1, 3, 5, 6, 14, 18 , 19 dan 24 berhubungan dengan terjadinya $\mathrm{DR} .^{8}$

Superantigen streptokokal adalah glikoprotein unik yang disintesa oleh bakteri dan virus yang dapat berikatan dengan major histocompatibility complex molecules dengan nonpolymorphic $\mathrm{V}$ b-chains dari T-cell receptors. Pada kasus streptokokus banyak penelitian yang difokuskan pada peranan superantigen-like activity dari fragmen M protein dan juga streptococcal pyrogenic exotoxin, dalam patogenesis DR. Terdapat bukti kuat bahwa respons autoimmune terhadap antigen streptokokkus memegang peranan dalam terjadinya DR dan PJR pada orang yang rentan. Sekitar $0,3-3$ persen individu yang rentan terhadap infeksi faringitis streptokokkus berlanjut menjadi DR. Data terakhir menunjukkan bahwa gen yang mengontrol low level respons antigen streptokokkus berhubungan dengan Class II human leukocyte antigen, HLA. Infeksi streptokokkus dimulai dengan ikatan permukaan bakteri dengan reseptor spesifik sel host dan melibatkan proses spesifik seperti pelekatan, kolonisasi dan invasi. Ikatan permukaan bakteri dengan permukaan reseptor host adalah kejadian yang penting dalam kolonisasi dan dimulai oleh fibronektin dan oleh streptococcal fibronectin-binding proteins. Faktor lingkungan seperti kondisi kehidupan yang jelek, kondisi tinggal yang berdesakan dan akses kesehatan yang kurang merupakan determinan yang signifikan dalam distribusi penyakit ini. Variasi cuaca juga mempunyai peran yang besar dalam terjadinya infeksi streptokokkus untuk terjadi DR. Pada gambar di bawah ini dapat dilihat skema patogenesis DR dan $\mathrm{PJR}^{8}$ 


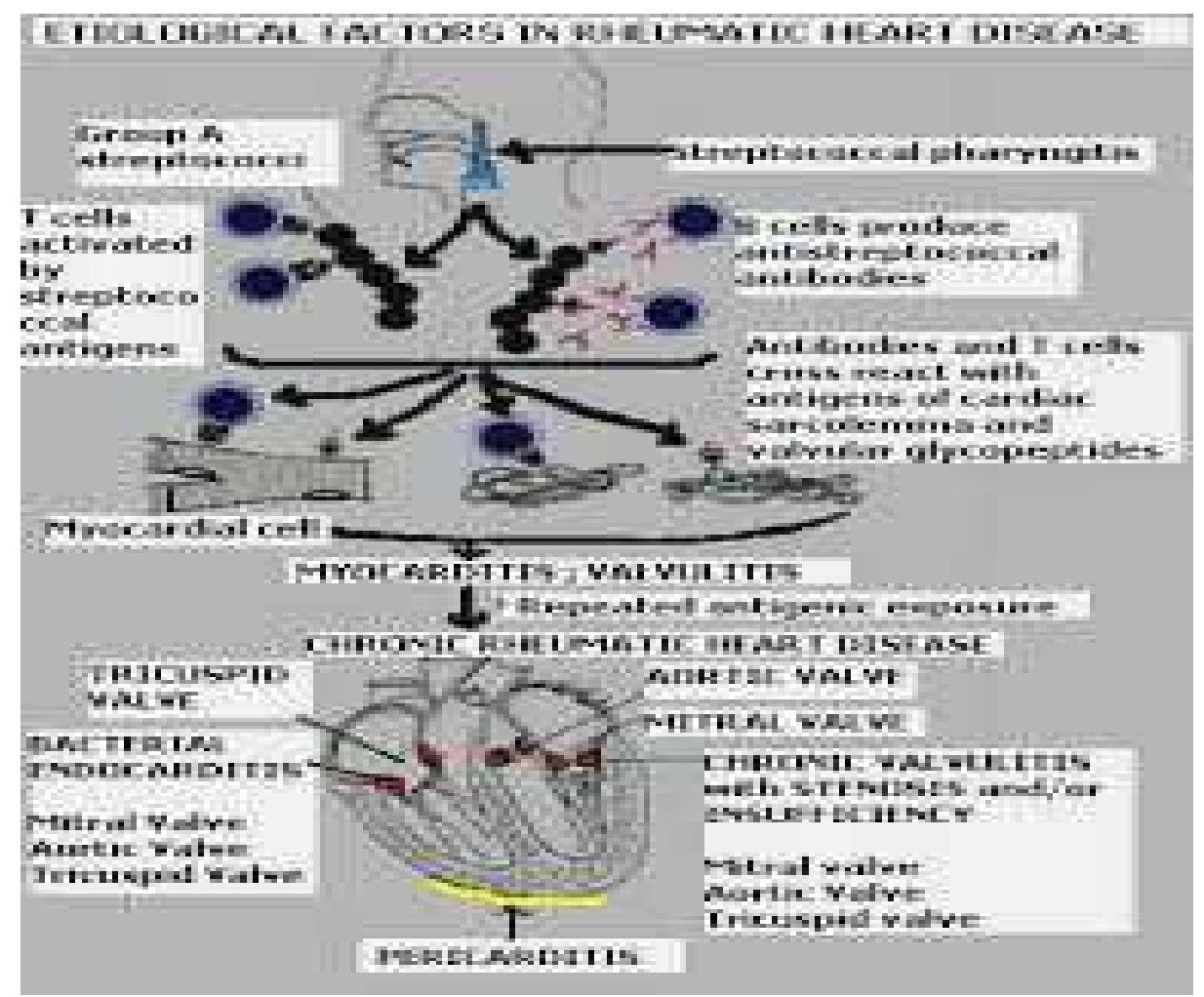

Gambar 1. Etiologi/Faktor Resiko Demam Reumatik

\section{PATOLOGI}

DR ditandai oleh radang eksudatif dan proliferatif pada jaringan ikat, terutama mengenai jantung, sendi dan jaringan subkutan. Bila terjadi karditis seluruh lapisan jantung akan dikenai. Perikarditis paling sering terjadi dan perikarditis fibrinosa kadang-kadang didapati. Peradangan perikard biasanya menyembuh setelah beberapa saat tanpa sekuele yang bermakna, dan jarang terjadi tamponade. Pada keadaan fatal, keterlibatan miokard menyebabkan pembesaran semua ruang jantung. Pada miokardium mula-mula didapati fragmentasi serabut kolagen, infiltrasi limfosit, dan degenerasi fibrinoid dan diikuti didapatinya nodul aschoff di miokard yang merupakan patognomonik DR. ${ }^{8}$

Nodul aschoff terdiri dari area nekrosis sentral yang dikelilingi limfosit, sel plasma, sel mononukleus yang besar dan sel giant multinukleus. Beberapa sel mempunyai inti yang memanjang dengan area yang jernih dalam membran inti yang disebut Anitschkow myocytes. Nodul Aschoff bisa didapati pada spesimen biopsi endomiokard penderita DR. Keterlibatan endokard menyebabkan valvulitis rematik kronis. Fibrin kecil, vegetasi verrukous, berdiameter 1-2 mm bisa dilihat pada 
permukaan atrium pada tempat koaptasi katup dan korda tendinea. Meskipun vegetasi tidak didapati, bisa didapati peradangan dan edema dari daun katup. Penebalan dan fibrotik pada dinding posterior atrium kiri bisa didapati dan dipercaya akibat efek jet regurgitasi mitral yang mengenai dinding atrium kiri. Proses penyembuhan valvulitis memulai pembentukan granulasi dan fibrosis daun katup dan fusi korda tendinea yang mengakibatkan stenosis atau insuffisiensi katup. Katup mitral paling sering dikenai diikuti katup aorta. Katup trikuspid dan pulmonal biasanya jarang dikenai. ${ }^{8}$

\section{MANIFESTASI KLINIS}

Perjalanan klinis penyakit demam reumatik/penyakit jantung reumatik dapat dibagi dalam 4 stadium:

\section{Stadium I}

Stadium ini berupa infeksi saluran napas bagian atas oleh kuman betaStreptococcus hemolyticus grup A. Keluhan biasanya berupa demam, batuk, rasa sakit waktu menelan, tidak jarang disertai muntah dan bahkan pada anak kecil dapat terjadi diare. Pada pemeriksaan fisik sering didapatkan eksudat di tonsil yang menyertai tandatanda peradangan lainnya. Kelenjar getah bening submandibular seringkali membesar. Infeksi ini biasanya berlangsung 2-4 hari dan dapat sembuh sendiri tanpa pengobatan ${ }^{8}$.

Para peneliti mencatat 50-90\% riwayat infeksi saluran napas bagian atas pada penderita demam reumatik/penyakit jantung reumatik, yang biasanya terjadi 10-14 hari sebelum manifestasi pertama demam reumatik/penyakit jantung reumatik ${ }^{8}$.

\section{Stadium II}

Stadium ini disebut juga periode laten, ialah masa antara infeksi Streptococcus dengan permulaan gejala demam reumatik, biasanya periode ini berlangsung 1-3 minggu, kecuali korea yang dapat timbul 6 minggu atau bahkan berbulan-bulan kemudian ${ }^{7}$.

\section{Stadium III}

Merupakan fase akut demam reumatik, saat timbulnya berbagai manifestasi klinik demam reumatik/penyakit jantung reumatik. Manifestasi klinik tersebut dapat digolongkan dalam gejala peradangan umum (gejala minor) dan manifestasi spesifik (gejala mayor) demam reumatik/penyakit jantung reumatik ${ }^{7}$.

\section{Stadium IV}


Disebut juga stadium inaktif. Pada stadium ini penderita demam reumatik tanpa kelainan jantung atau penderita penyakit jantung reumatik tanpa gejala sisa katup tidak menunjukkan gejala apa-apa ${ }^{7}$.

Pada penderita penyakit jantung reumatik dengan gejala sisa kelainan katup jantung, gejala yang timbul sesuai dengan jenis serta beratnya kelainan. Pada fase ini baik penderita demam reumatik maupun penyakit jantung reumatik sewaktu-waktu dapat mengalami reaktivasi penyakitnya ${ }^{7}$.

\section{a. Manifestasi Klinis Mayor}

\section{Karditis}

Frekuensi karditis 30-60\% pada serangan pertama, dan sering pada anak anak. Karditis adalah satu satunya komplikasi. Demam reumatik yang bisa menimbulkan efek jangka panjang. Kelainannya berupa pankarditis, yaitu mengenai perikardium, epikardium, miokardium dan endokardium. Pada Demam reumatik sering terjadi pankarditis yang ditandai dengan perikarditis, myokarditis dan endokarditis. ${ }^{9}$

Perikarditis ditandai dengan pericardial friction rub. Pada efusi perikard bisa didengar adanya muffled sound, dan pulsus paradoks ( penurunan tekanan sistolik yang besar di saat inspirasi). Karakterisitik miokarditis adalah infiltrasi sel mononuklear, vaskulitis dan perubahan degeneratif pada interstisial conective tissue. Bentuk endokarditis tersering adalah insufisiensi katub mitral. ${ }^{10}$

Katub yang sering terkena adalah katub mitral (65-70\%) dan katub aorta (25\%). Katub trikuspid hanya terganggu pada $10 \%$ dan hampir selalu berhubungan lesi pada katub mitral dan aorta. Sedangkan katub pulmonal sangat jarang terlibat.Insufisiensi katub yang berat pada fase akut dapat menyebabkan gagal jantung dan kematian (pada $1 \%$ penderita). Perlengketan pada jaringan penunjang katub akan menghasilkan stenosis atau kombinasi antara stenosis dan insufisiensi yang muncul dalam 2-10 tahun setelah episode demam reumatik akut. Perlengketan bisa terjadi pada tingkatan ujung bilah katub, bilah katub dan chorda atau kombinasi dari ketiga tingkatan tersebut ${ }^{10}$

- Bising jantung yang sering pada demam rematik:

- Bising mitral regurgitasi berupa bising pansistolik, high pitch, yang radiasi ke axilla. Tidak dipengaruhi oleh posisi dan respirasi. Intensitas 2/6.

- Carey coombs bising : bising diastolik di apeks pada karditis yang aktif dan menyertai mitral insufisiensi berat. Mekanismenya berupa relatif mitral stenosis 
yang diakibatkan dari volume yang besar yang melalui katub mitral saat pengisian ventrikel.

- Bising aorta regurgitasi : bising awal diastolik yang terdapat dibasal, dan terbaik didengar pada sisi atas kanan dan kiri sternum saat penderita duduk miring kedepan. ${ }^{10}$

\section{Artritis}

Artritis ARF paling sering menyerang sendi-sendi besar, terutama lutut, pergelangan kaki, siku, dan pergelangan tangan. Banyak sendi yang sering terlibat, dengan timbulnya artritis pada sendi yang berbeda baik dipisahkan dalam waktu atau tumpang tindih, sehingga memunculkan deskripsi "polyratritis" migrasi "atau" aditif ". Setiap sendi terpengaruh selama beberapa hari hingga satu minggu, dengan seluruh episode sembuh tanpa pengobatan dalam waktu satu bulan. Nyeri sendi bisa sangat parah, terutama pada anak-anak yang lebih tua dan remaja, dan sering tidak sesuai dengan tanda-tanda klinis peradangan ${ }^{11}$

Atralgia yang merupakan suatu kriteria minor, juga sering menyebabkan seorang dokter mendiagnosa sebagai Demam reumatik terutama jika terdapat kriteria minor yang lain, seperti febris dan bukti adanya infeksi streptokukkus seperti ASTO. Penelitian di RS Hasan sadikin bandung menunjukkan terdapat 24 kasus dari 113 kasus dengan atralgia dan febris, yang setelah ditelaah ulang, tidak memenuhi kriteria Jones, hasil ekokardiografi juga tidak menunjukkan adanya tanda-tanda karditis. ${ }^{9}$

\section{Chorea Sydenham}

Insidensi sydenham chorea muncul dalam 1-6 bulan setelah infeksi streptokokus, progresif secara perlahan dan memberat dalam 1-2 bulan.Kelainan neurologis berupa gerakan involunter yang tidak terkoordinasi (choreiform), pada muka, leher, tangan dan kaki. Disertai dengan gangguan kontraksi tetanik dimana penderita tidak bisa menggenggam tangan pemeriksa secara kuat terus menerus (milk sign). ${ }^{12}$

Chorea dapat muncul dengan sendirinya, tanpa ciri-ciri ARF lainnya dan tanpa bukti infeksi streptokokus, karena chorea dapat terjadi berbulan-bulan setelah infeksi streptokokus. Jika chorea memiliki presentasi yang terisolasi, penting untuk mengecualikan penyebab lain dari chorea, seperti systemic lupus erythematosus, penyakit Wilson, dan reaksi. Dalam semua kasus yang dicurigai chorea reumatik, pemeriksaan jantung dan ekokardiogram harus dilakukan, karena chorea sangat terkait dengan carditis ${ }^{11}$ 


\section{Eritema Marginatum}

Muncul dalam 10\% serangan pertama Demam reumatik biasanya pada anak anak, jarang pada dewasa.Lesi berwarna merah, tidak nyeri dan tidak gatal dan biasanya pada batang tubuh, lesi berupa cincin yang meluas secara sentrifugal sementara bagian tengah cincin akan kembali normal. ${ }^{10}$

\section{Nodulus Subkutan}

Nodul subkutan muncul beberapa minggu setelah onset demam rematik, dan biasanya tidak disadari penderita karena tidak nyeri. Biasanya berkaitan dengan karditis berat, lokasinya di permukaan tulang dan tendon, serta menghilang setelah 1-2 minggu.

\section{B. Manifestasi Minor}

Demam hampir selalu ada pada poliartritis reumatik; ia sering ada pada karditis yang tersendiri (murni) tetapi pada korea murni. Jenis demamnya adalah remiten, tanpa variasi diurnal yang lebar, gejala khas biasanya kembali normal atau hampir normal dalam waktu $2 / 3$ minggu, walau tanpa pengobatan. Artralgia adalah nyeri sendi tanpa tanda objektif pada sendi. Artralgia biasanya melibatkan sendi besar. Kadang nyerinya terasa sangat berat sehingga pasien tidak mampu lagi menggerakkan tungkainya ${ }^{13}$.

Termasuk kriteria minor adalah beberpa uji laboratorium. Reaktan fase akut seperti LED atau C-reactive protein mungkin naik. Uji ini dapat tetap naik untuk masa waktu yang lama (berbulan-bulan). Pemanjangan interval PR pada elektrokardiogram juga termasuk kriteria minor ${ }^{13}$.

Nyeri abdomen dapat terjadi pada demam reumatik akut dengan gagal jantung oleh karena distensi hati. Nyeri abdomen jarang ada pada demam reumatik tanpa gagal jantung dan ada sebelum manifestasi spesifik yang lain muncul. Pada kasus ini nyeri mungkin terasa berat sekali pada daerah sekitar umbilikus, dan kadang dapat disalahtafsirkan sebagai apendistis sehingga dilakukan operasi ${ }^{13}$.

Anoreksia, nausea, dan muntah seringkali ada, tetapi kebanyakan akibat gagal jantung kongestif atau akibat keracunan salisilat. Epitaksis berat mungkin dapat terjadi. Kelelahan merupakan gejala yang tidak jelas dan jarang, kecuali pada gagal jantung. Nyeri abdomen dan epitaksis, meskipun sering ditemukan pada demam reumatik, tidak dianggap sebagai kriteria diagnosis ${ }^{13}$. 


\section{DIAGNOSIS}

Diagnosis DRA ditegakkan berdasarkan kriteria jones dan salah satu kriteria mayor adalah karditis yang menunjukkan adanya keterlibatan katup jantung dan dapat diperkirakan secara klinis dengan terdapatnya murmur pada pemeriksaan auskultasi, namun seringkali klinisi yang berpengalamanpun tidak mendengar adanya murmur padahal sudah terdapat keterlibatan katup pada pasien tersebut. Keterlibatan katup seperti ini dinamakan karditis/ valvulitis subklinis.Saat ini, diagnosis DRA ditegakkan berdasarkan Kriteria Jones.namun dalam praktek sehari- hari tidak mudah untuk menerapkankan hal tersebut. 8 Untuk Diagnosa diperlukan : 2 kriteria mayor atau 1 kriteria mayor dan 2 kriteria minor dan bukti infeksi oleh sterptokokus grup A. Kecuali bila ada chorea atau karditis maka bukti infeksi sebelumnya tidak diperlukan.

Tabel 1. Kriteria Jones Demam Reumatik Akut

\begin{tabular}{ll}
\hline \multicolumn{1}{c}{ Kriteria Mayor } & \multicolumn{1}{c}{ Kriteria minor } \\
\hline 1. Karditis & 1. Demam \\
2. Polyarthritis & 2. Polyatralgia \\
3. Chorea & 3. Laboratorium: Peningkatan acute \\
4. Erythema marginatum & phase reaction (LED atau Leukosit) \\
5. Subcutaneous nodul & 4. PR interval memanjang
\end{tabular}

Kriteria Jones telah mengalami beberapa revisi untuk meningkatkan nilai spesifitas nya.Untuk negara negara resiko tinggi demam rematik.World Health Organization (WHO) telah membuat kriteria yang lebih menitikberatkan pada sensitifitas dibandingkan spesifitas

Tabel 2. Klasifikasi Diagnosis Demam Reumatik dan Penyakit Jantung Reumatik WHO 2002-2003

Grup Klasifikasi




\begin{tabular}{ll}
\hline A & Demam rematik serangan pertama: 2 kriteria major atau 1 kriteria major dan 2 minor \\
& + Streptokokus B hemolitikus grup A bukti infeksi sebelumnya. \\
B & Demam reumatik serangan rekuren tanpa penyakit jantung reumatik: 2 major atau \\
& major dan 2 minor + bukti Streptokokus B hemolitikus grup A sebelumnya. \\
C & Demam reumatik serangan rekuren dengan penyakit jantung reumatik: 2 minor + \\
& bukti Streptokokus B hemolitikus grup A sebelumnya. \\
D & Chorea Syndenham tidak perlu criteria major lainnya atau bukti Streptokokus B \\
& hemolitikus grup A \\
E & Penyakit jantung reumatik (stenosis mitral murni atau kombinasi dengan insufisiensi \\
& dan atau gangguan aorta) tidak perlu criteria lain.
\end{tabular}

a. Pemeriksaan Laboratorium ${ }^{10,12,14,15}$

- Kultur tenggorokan merupakan gold standard untuk konfirmasi infeksi strptokokus grup A.

- Pemeriksaan antigen cepat tidak sesenstif kultur tenggorokan, sehingga apabila hasilnya negatif tetap perlu dilakukan kultur tenggorokan. Dengan spersifitasnya yang tinggi apabila hasil pemeriksaan antigennya positif merupakan konfirmasi infeksi streptokokus grup A. Pemeriksaan titer antibodi menggunakan antistreptolisin O (ASO), antistreptococcal DNAse B (ADB) dan antistreptococcal hyaluronidase (AH). i) ASO untuk mendeteksi antibodi streptokokus terhadap streptokokus lysin O, peningkatan titer 2 kali lipat menunjukkan bukti infeksi terdahulu. ii) Pemeriksaan antibodi ini harus berhati hati pada daerah dengan infeksi streptokokus yang tinggi, karena kadar titer yang tinggi secara umum pada populasi tersebut.

- Reaktan fase akut : C reactive protein (CRP) dan lanju endap darah akan meningkat pada DRAakut, merupakan kriteria minor dari jones.

- Kultur darah berguna untuk menyingkirkan infektif endokarditis, bakteremia dan infeksi gonokokus.

\section{Tabel 3. Evidence of antecedent group A streptococcal infection}

\begin{tabular}{llll}
\hline Sampel Description & Test Characteristics & Upper limits of normal \\
\hline
\end{tabular}




\begin{tabular}{|c|c|c|c|c|}
\hline Blood & $\begin{array}{ll}\text { Antistreptolysin } & \mathrm{O} \\
\text { titre (ASTO) } & \end{array}$ & 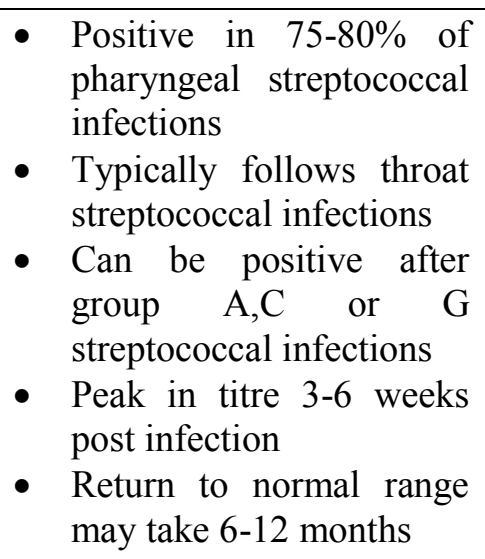 & $\begin{array}{l}\text { Age } \\
1-4 \\
5-14 \\
15-24 \\
25-34 \\
>35\end{array}$ & $\begin{array}{l}\text { ULN (U/mL) } \\
170 \\
276 \\
238 \\
177 \\
127\end{array}$ \\
\hline Blood & AntiDNAseB titre & $\begin{array}{l}\text { - Typically follows throat } \\
\text { and skin streptococcal } \\
\text { infections } \\
\text { - More specific than ASOT } \\
\text { for Group A } \\
\text { streptococcal infections } \\
\text { - Peak in titre 6-8 weeks } \\
\text { post infection } \\
\text { - Return to normal range } \\
\text { may take 6-12 months }\end{array}$ & $\begin{array}{l}\text { Age } \\
1-4 \\
5-14 \\
15-24 \\
25-34 \\
>35\end{array}$ & $\begin{array}{l}\text { ULN (U/mL) } \\
366 \\
499 \\
473 \\
390 \\
265\end{array}$ \\
\hline $\begin{array}{l}\text { Pharyngeal } \\
\text { (bacterial in } \\
\text { transport } \\
\text { medium) }\end{array}$ & $\begin{array}{l}\text { Group A beta } \\
\text { hemolytic } \\
\text { streptococcus } \\
\text { cultured from } \\
\text { pharyngeal swab }\end{array}$ & \multicolumn{3}{|c|}{$\begin{array}{l}\text { Often culture- negative by the time symptomatic. ARF } \\
\text { is evident however a positive result provides the } \\
\text { required proof to make the ARF diagnosis even if } \\
\text { serological titre for ASOT/ anti-DNAseB are below } \\
\text { cutoff }\end{array}$} \\
\hline
\end{tabular}

b. Foto toraks ${ }^{10,12,14,15}$

Pada pasien karditis dan gagal jantung foto thorak akan timbul kardiomegali

c. Elektrokardiografi ${ }^{10,12,14,15}$

Kelainan yang terpenting adalah PR interval memanjang ( kriteria minor jones) tetapi bukan bukti adanya karditis. Kelainan lain yang bisa muncul : Blok derajat 2 dan 3. Pada penderita penyakit jantung rematik kronis bisa ditemukan pembesaran atrium kiri akibat dari mitral stenosis.

d. Ekokardiografi ${ }^{10,12,14,15}$

Penelitian yang dilakukan di RS Hasan Sadikin Bandung tentang peranan ekokardiografi dalam mendiagnosis DRA menunjukkan menunjukkan sensitifitas dan spesifisitas ekokardiografi ditemukan 89,4\% dan 38,7\% .Sehingga ekokardiografi dapat disarankan untuk dimasukkan dalam algoritma DRA. ekokardiografi dapat disarankan dimasukkan dalam algoritma diagnosa DRA dengan menambahkan pemeriksaan ekokardiografi untuk menegakkan kriteria mayor karditis. 


\section{PENGOBATAN ${ }^{16}$}

Tatalaksana komprehensif pada pasien dengan demam rematik meliputi:

- Pengobatan manifestasi akut, pencegahan kekambuhan dan pencegahan endokarditis pada pasien dengan kelainan katup.

- Pemeriksaan ASTO, CRP, LED, tenggorok dan darah tepi lengkap. Ekokardiografi untuk evaluasi jantung.

- Antibiotik: penisilin, atau eritromisin $40 \mathrm{mg} / \mathrm{kgBB} / \mathrm{hari}$ selama 10 hari bagi pasien dengan alergi penisilin. Sesudah pengobatan DRA selama 10 hari dilanjutkan dengan pencegahan sekunder. Cara pencegahan sekunder yang diajukan oleh The American Heart Association dan WHO, yaitu mencegah infeksi streptokokus. ${ }^{16}$

a. Pencegahan primer

Penisilin oral untuk eradikasi Streptococcus beta hemolyticus group A selama 10 hari atau benzathine penicillin G 0.6-1.2 juta unit IM

b. Pencegahan sekunder

Benzantin penisilin G $600.000 \mathrm{U}$ IM untuk berat badan $<27 \mathrm{~kg}$ (60 pound), 1,2 juta $U$ untuk berat badan $>27 \mathrm{~kg}$ (60 pound) setiap 4 minggu/28 hari

Pilihan lain: Penisilin V p.o.125-250mg 2 kali sehari Sulfadiazin 1 g p.o. sekali sehari Eritromisin --250 mg p.o. 2 kali sehari Diberikan pada demam reumatik akut, termasuk korea tanpa penyakit jantung reumatik.

\section{Tabel 4. Lama pencegahan Demam Reumatik}

\begin{tabular}{|c|c|}
\hline Kategori pasien & Durasi \\
\hline Demam rematik tanpa karditis & $\begin{array}{l}\text { Sedikitnya sampai } 5 \text { tahun setelah serangan terakhir } \\
\text { atau hingga usia } 18 \text { tahun }\end{array}$ \\
\hline $\begin{array}{ll}\text { Demam rematik dengan } \\
\text { karditis tanpa bukti } & \text { adanya } \\
\text { penyakit } & \text { jantung } \\
\text { residual/kelainan katup. }\end{array}$ & $\begin{array}{l}\text { Sedikitnya sampai } 10 \text { tahun setelah serangan } \\
\text { terakhir atau hingga usia } 25 \text { tahun, dipilih jangka } \\
\text { waktu yang terlama }\end{array}$ \\
\hline $\begin{array}{l}\text { Demam reumatik akut dengan } \\
\text { karditis dan penyakit jantung } \\
\text { residual (kelainan katup } \\
\text { persisten) }\end{array}$ & $\begin{array}{l}\text { Sedikitnya } 10 \text { tahun sejak episode terakhir atau } \\
\text { sedikitnya hingga usia } 40 \text { tahun, dan kadang- } \\
\text { kadang seumur hidup }\end{array}$ \\
\hline Setelah operasi katup & Seumur hidup \\
\hline
\end{tabular}

- $\quad$ Tirah baring bervariasi tergantung berat ringannya penyakit. 
- Anti inflamasi: dimulai setelah diagnosis ditegakkan:

Bila hanya ditemukan artritis diberikan asetosal $100 \mathrm{mg} / \mathrm{kgBB} / \mathrm{hari}$ sampai 2 minggu, kemudian diturunkan selama 2-3 minggu berikutnya.

Pada karditis ringan-sedang diberikan asetosal 90-100 mg/kgBB/hari terbagi dalam 4-6 dosis selama 4-8 minggu bergantung pada respons klinis. Bila ada perbaikan, dosis diturunkan bertahap selama 4-6 minggu berikutnya.

Pada karditis berat dengan gagal jantung ditambahkan prednison 2 $\mathrm{mg} / \mathrm{kgBB} /$ hari diberikan selama 2-6 minggu.

Tabel 5. Tatlaksana Demam Reumatik Akut

\begin{tabular}{|c|c|c|c|}
\hline Manifestasi Klinis & Tirah Baring & $\begin{array}{l}\text { Obat } \\
\text { Inflamasi }\end{array}$ & Kegiatan \\
\hline Artritis tanpa karditis & $\begin{array}{l}\text { Total } 2 \text { minggu } \\
\text { Mobilisasi bertahap } \\
2 \text { minggu }\end{array}$ & $\begin{array}{lr}\text { Asetosal } & 100 \\
\mathrm{mg} / \mathrm{kgBB} & \text { selama } 2 \\
\text { minggu. } & \\
75 & \mathrm{mg} / \mathrm{kgBB} \\
\text { selama } 4 & \text { minggu } \\
\text { berikutnya }\end{array}$ & $\begin{array}{l}\text { Masuk sekolah } \\
\text { setelah } 2 \text { minggu } \\
\text { Bebas berolahraga }\end{array}$ \\
\hline $\begin{array}{l}\text { Artritis }+ \text { karditis } \\
\text { tanpa kardiomegali }\end{array}$ & $\begin{array}{l}\text { Total } 4 \text { minggu } \\
\text { Mobilisasi bertahap } \\
4 \text { minggu }\end{array}$ & Sama dengan diatas & $\begin{array}{l}\text { Masuk sekolah } \\
\text { setelah } 8 \text { minggu } \\
\text { Bebas berolahraga }\end{array}$ \\
\hline $\begin{array}{l}\text { Artritis }+ \\
\text { kardiomegali }\end{array}$ & $\begin{array}{l}\text { Total } 6 \text { minggu } \\
\text { Mobilisasi bertahap } \\
6 \text { minggu }\end{array}$ & $\begin{array}{l}\text { Prednison } 2 \\
\mathrm{mg} / \mathrm{kgBB} \text { selama } 2 \\
\text { minggu tapering off } \\
\text { selama } 2 \text { minggu. } \\
\text { Asetosal } \\
\mathrm{mg} / \mathrm{kgBB} \text { mulai } \\
\text { awal minggu ke-3 } \\
\text { selama } 6 \text { minggu }\end{array}$ & $\begin{array}{l}\text { Masuk sekolah } \\
\text { setelah } 12 \text { minggu } \\
\text { Jangan olahraga } \\
\text { berat atau kompetitif }\end{array}$ \\
\hline $\begin{array}{l}\text { Artritis }+ \\
\text { kardiomegali+ } \\
\text { Dekompresi kordis }\end{array}$ & $\begin{array}{l}\text { Total selama } \\
\text { dekompensasi kordis } \\
\text { Mobilisasi bertahap }\end{array}$ & Sama dengan diatas & $\begin{array}{l}\text { Masuk sekolah } \\
\text { setelah1 } 2 \text { minggu } \\
\text { Dekompesasi } \\
\text { teratasi } \\
\text { Dilarang olahraga 2- } \\
5 \text { th }\end{array}$ \\
\hline
\end{tabular}

\section{PROGNOSIS $^{16}$}

Morbiditas demam reumatik akut berhubungan erat dengan derajat keterlibatan jantung. Mortalitas sebagian besar juga akibat karditis berat, komplikasi yang sekarang sudah jarang terlihat di negara maju (hampir 0\%) namun masih sering ditemukan di negara berkembang (1-10\%). Selain menurunkan mortalitas, perkembangan penisilin juga mempengaruhi kemungkinan berkembangnya menjadi penyakit valvular kronik 
setelah serangan demam reumatik aku. Sebelum penisilin, persentase pasien berkembang menjadi penyakit valvular yaitu sebesar $60-70 \%$ dibandingkan dengan setelah penisilin yaitu hanya sebesar $9-39 \%{ }^{18}$

\section{DAFTAR PUSTAKA}

1. Alyssa, F.S. , Roro, R.. Penyakit Jantung Rematik pada Anak Laki-laki Usia 8 Tahun. J Medula Unila 7(2). 2017.

2. Rahayuningsih SE, Farrah A. Role of echoacardiography in diagnose of acute rhematic fever Paediatrica Indonesiana Vol 50 no 2 (supplement) March 2010

3. Alan Bisno, E.G.B., NK Ganguly, WHO Expert Consultation on Rheumatic Fever and Rheumatic Heart Disease, in WHO technical report series. World Health Organization: Geneva. 2001.

4. WHO. Rhematic fever and rheumatic heart disease.-report of a WHO expert Consultation. 2018.

5. Flyer DC. Rheumatic fever. Dalam: Keane JF, Lock JE, Flyer DC. Nadas' pediatric cardiology. Edisi ke-2. Philadelphia: Elsevier: h. 387-400.2006.

6. Tanto, C. Kapita Selekta Kedokteran Edisi ke-4 Jilid 1. Jakarta: Media Aesculapius: hal 76-78. 2014.

7. Pusponegoro HD. Standar Pelayanan Medis Kesehatan Anak Edisi 1. Jakarta: Badan Penerbit IDAI: hal 149-153. 2004.

8. Abdullah, A. Demam Reumatik dan Penyakit Jatung Reumatik Permasalahan Indonesia.Jurnal Universitas Sutamtera Utara. 2008.

9. Rahayuningsih SE, Farrah A. Role of echoacardiography in diagnose of acute rhematic fever Paediatrica Indonesiana Vol 50 no 2 (supplement). March 2010.

10. Turi, B.S.R.Z.G., Rheumatic Fever, in Braunwald's Heart Disease A Textbook of Cardiovascular Medicine, M.P.L. Eugene Braunwald, MD Robert O. Bonow, MD, Editor. Saunders Elsevier: Philadelphia. 2007.

11. Dianne dkk. Acute rheumatic fever and rheumatic heart disease. Jurnal NCBI.;8(4):324-30. 2017.

12. Flyer DC. Rheumatic fever. Dalam: Keane JF, Lock JE, Flyer DC. Nadas' pediatric cardiology. Edisi ke-2. Philadelphia: Elsevier; h. 387-400.2006.

13. Behrman, R.E. Nelson, Ilmu Kesehatan Anak vol. 2 Ed. 15. Jakarta: EGC; hal 929-935. 1999.

14. Scott, dkk. Rheumatic heart disease screening: Current concepts and challenges. Jurnal NCBI: 10(1). 2017.

15. Mishra TK. Acute rheumatic fever and rheumatic heart disease: current scenario. JIACM;8(4):324-30.2007.

16. Hospital Care for Children. Demam Rematik. http://www.ichrc.org/610-demamreumatik-akut. 2016. 